\title{
Wybawca Wittgenstein? Problem regut w teorii praktyki Pierre'a Bourdieu
}

\author{
Magdalena Pancewicz-Puchalska
}

\begin{abstract}
Abstrakt: Tekst stanowi dociekliwą i wyczerpującą analizę wpływu filozofii Ludwiga Wittgensteina na teorię praktyki Pierre'a Bourdieu, a zwłaszcza na wypracowane przez Bourdieu pojęcia zmysłu praktycznego i logiki praktycznej. Autorka rozważa stosunek do obiektywizmu obu filozofów. Następnie proponuje takie odczytanie teorii Wittgensteina, które mogłoby okazać się pożyteczne i inspirujące w polu socjologicznym. W ostatniej części artykułu autorka analizuje inne, po części opozycyjne wobec teorii Pierre’a Bourdieu teorie praktyki, zaproponowane przez Anthony’ego Giddensa i Michela de Certeau i stawia je w świetle analiz Wittgensteina.

Wyrażenia kluczowe: Pierre Bourdieu; Ludwig Wittgenstein; habitus.
\end{abstract}

Wittgenstein jest prawdopodobnie filozofem najbardziej mi pomocnym w trudnych momentach. Jest kimś w rodzaju wybawcy w chwilach ogromnych intelektualnych katuszy - jak wtedy, gdy trzeba zakwestionować tak oczywiste rzeczy, jak „postępowanie według reguły" albo gdy trzeba opisać tak proste (i zarazem praktycznie niewyrażalne) kwestie, jak praktykowanie praktyki (Bourdieu, 1990, s. 9).

Przezwyciężanie opozycji agency/structure czy, w terminach częściej występujących u Pierre'a Bourdieu, obiektywizm/subiektywizm to temat trwale obecny w pracach socjologa ${ }^{1}$. W ogólniejszych terminach filozoficznych antynomia ta przyjmuje w ujęciu Bourdieu postać sporu determinizmu z mechanicyzmem czy woluntaryzmu z idealizmem. W zmaganiu z tą antynomią pomocna jest Bourdieu filozofia Wittgensteina.

Jak twierdzi Loïc Wacquant, koncepcje habitusu i pola (champ), kluczowe elementy teorii praktyki Bourdieu, pozwalają „uwolnić się od fałszywego problemu osobistej spontaniczności i przymusu społecznego, wolności i konieczności, wyboru i obowiązku” (Wacquant, 2001, s. 25). Pojęcie habitusu ma, zgodnie z duchem Wittgensteinowskich Dociekań filozoficznych, kwestionować obiektywistyczny model postępowania jako „kierowania się regułą”, a także wydobywać specyfikę praktyk - ich płynność, niesystematyczność, improwizacyjny i strategiczny charakter. Mimo że nie są posłuszne regułom, praktyki podlegają koniecznym regularnościom i ograniczeniom:

1 Meandryczne losy kategorii obiektywizm i subiektywizm w socjologii uważnie prześledził Jerzy Szacki (1991). David Swartz podsumowuje, że w użyciu Bourdieu są one wieloznaczne i nieprecyzyjne: czasem „dychotomia ta odsyła do opozycji między podejściami interpretatywnymi i pozytywistycznymi do społecznej rzeczywistości, czasem przeciwstawia sobie poziom mikro i makro analizy, kiedy indziej zaś wskazuje na opozycję między obserwatorem uczestniczącym a zewnętrznym" (Swartz, 1997, s. 53). 
Przejście od regularności, czyli tego, co wydarza się z pewną statystycznie mierzalną częstością i w sposób możliwy do wyjaśnienia, do świadomie głoszonej i świadomie przestrzeganej regulacji bądź też do nieświadomej regularności tajemniczej mechaniki mózgu to dwa najpoważniejsze sposoby przesunięcia od modelu rzeczywistości do realności modelu (Bourdieu, 2008, s. 52).

Bourdieu sądzi, że w swym ambitnym naukowym projekcie zbliża się na tyle, na ile to możliwe, do rzeczywistości samych praktyk.

Fundamentalnym założeniem teorii Bourdieu jest to, że większość naszych działań wykonujemy dzięki praktycznej kompetencji, milczącej wiedzy i nieteoretycznej umiejętności ich stosowania. Habitus to rodzaj praktycznego zmysłu (sens pratique) pozwalającego orientować się w świecie społecznym i ukształtowanego przez „zasady kulturowej arbitralności” (Bourdieu, 2008, s. 95). Składają się nań dyspozycje cielesne i mentalne, schematy myślenia, percepcji i działania. Z jednej strony Bourdieu podkreśla spontaniczność i zdolności inwencyjne charakterystyczne dla habitusu, z drugiej - skłonność habitusu do odtwarzania warunków swojego wytworzenia (np. relacji dominacji i podporządkowania, reprodukcji rozkładu kapitału społecznego, kulturowego, symbolicznego w społeczeństwie) (Bourdieu, 2007, s. 197, 2008, s. 82). Ma on obejmować oba momenty: obiektywny (działanie społecznych struktur na podmioty) i subiektywny (struktury mentalne i wcielone schematy, działanie podmiotu).

Jak wskazuje cytat wybrany przeze mnie na motto, wpływ późnego Wittgensteina na Bourdieu jest niewątpliwy. Sądzę, że rysy Wittgensteinowskiego myślenia są widoczne przede wszystkim w teorii praktyki Bourdieu, ogólnej dziedzinie obejmującej między innymi krytykę intelektualizmu („rozumu scholastycznego”) i analizę (czy odrzucenie?) ujmowania „praktykowania praktyki” jako postępowania według regut. Autor pracy Social Practices: A Wittgensteinian Approach to Human Activity and the Social także zalicza Bourdieu do grona filozofów i badaczy zainspirowanych tym, co uznaje za intuicję Wittgensteinowską: „to, co społeczne, i społeczny kontekst indywidualnego życia są zbiorem praktyk" (Schatzki, 1996, s. 103)². Jednak w dorobku Bourdieu efekty tego oddziaływania są rozproszone i trudne do oddzielenia od śladów dziedzictwa innych autorów (Maurice’a Merleau-Ponty’ego, Karola Marksa, Émila Durkheima, Gastona Bachelarda, Georgesa Canguillhema, Maxa Webera, Claude’a Lévi-Straussa, Marcela Maussa etc.).

\section{Trudności metodologiczne}

Marie McGinn stwierdza, że „wnioski” Wittgensteina są często niejasne, a każda próba destylowania z jego uwag teoretycznych objaśnień idzie na przekór jego metodzie

2 Istnienie zróżnicowanego, ale dającego się wyodrębnić nurtu teorii praktyk diagnozuje między innymi Schatzki w pracy Practice Turn in Contemporary Theory (Schatzki, Knorr-Cetina, \& Savigny, 2001). O tym oraz o podejmowanych przez Bourdieu wątkach fenomenologii ciała pisałam w tekście Praktykowanie kultury poprzez ciało - o pewnych wątkach fenomenologicznych w socjologii Pierre’a Bourdieu (Pancewicz-Puchalska, 2011). 
i stylowi - nietworzącym całości, szkicowym, polifonicznym, pełnym powtórzeń (McGinn, 1997, s. 110). Podsumowując rozdział o kierowaniu się regułami (rule following), McGinn pisze, iż prawdziwą lekcją, jaką dają uwagi Wittgensteina, jest „reorientacja naszego sposobu myślenia, odejście od abstrakcji i uogólnień w stronę wytężonej uwagi w stosunku do tego, co mamy przed oczami” (McGinn, 1997, s. 111). Stwierdzenie to, rozpatrywane oddzielnie, mówi o jednej cesze Wittgensteinowskiego stylu filozofowania. Czy można powiedzieć, że sposób myślenia danego teoretyka jest utrzymany „w duchu” Wittgensteinowskim? Przypuszczenie to nie jest tak powierzchowne, jak mogłoby się zrazu zdawać, wziąwszy pod uwagę awersję Wittgensteina do teorii, którą potwierdzają słowa z Dociekań filozoficznych: „Nie wolno nam też formułować żadnych teorii” (Wittgenstein, 2008, s. 72). Ponadto jednym z celów, jakie Wittgenstein sobie stawiał, była zmiana stosunku czytelników jego pism do problemów filozoficznych. Wydaje się, że zrealizował on swoje zamierzenie. Tę ocenę można odnieść do licznych myślicieli, którzy przynajmniej częściowo się z nim zgadzają lub sądzą, że nie można przeoczyć nowego sposobu, w jaki potraktował kwestie filozoficzne. Bourdieu jest z całą pewnością jednym z takich badaczy.

Wacquant, uczeń i komentator Bourdieu, cytuje Wittgensteina, aby wyjaśnić lub zilustrować twierdzenia i dokonania swego nauczyciela: „Tym, którzy narzekają, że jego pojęcia są «nieostre» [...] Bourdieu mógłby odpowiedzieć słowami Wittgensteina: «jeśli pojęcie zależy od formy życia, musi cechować je pewna nieokreśloność»" (Wacquant, 1992, s. 23) ${ }^{3}$. Rzeczywiście Bourdieu łączy z Wittgensteinem podejrzliwość wobec teoretyzowania, a swoje koncepcje traktuje jak „skrzynki z narzędziami” - zgodnie ze słynną metaforą z paragrafu 11 Dociekań. Philip Gerrans, komentując teorię praktyki Bourdieu, przyznaje: „Myślę, że jest to coś w rodzaju stanowiska wittgensteinowskiego, ale trzeba zauważyć, że bardziej z uwagi na podejście (attitude) niż argumentację" (Gerrans, 2005, s. 63). Potwierdza więc niejako tezę o trudno uchwytnym pokrewieństwie między ideami francuskiego socjologa i austriackiego filozofa.

Dotykamy tu ważnego i ogólnego problemu - pisania o Wittgensteinie i interpretowania jego spuścizny. Pamiętając o tych niebłahych trudnościach, postaram się jednak nakreślić możliwie przekonujący obraz stosunku Bourdieu do Wittgensteina ze szczególnym uwzględnieniem teorii praktyki tego pierwszego. Spróbuję zarysować pewien porządek „służący określonemu celowi; jeden z wielu możliwych porządków, nie zaś porządek w ogóle" (Wittgenstein, 2008, s. 77).

\section{Język: system kontra dziatanie}

Pierwszą część Zmysłu praktycznego, zatytułowaną „Krytyka teoretycznego rozumu”, rozpoczyna dobrze znany cytat z Dociekań filozoficznych:

3 Słów tych brak w polskim przekładzie wprowadzenia do Zaproszenia do socjologii refleksyjnej. Cytat pochodzi z pracy Wittgensteina Remarks on Philosophy of Psychology (Wittgenstein, 1980b, s. 653). 
„ Jak można kierować się regułą?” - jeżeli nie jest to pytanie o przyczyny, to jest pytaniem o usprawiedliwienie, dlaczego tak według niej postępuję.

Wyczerpawszy uzasadnienia, docieram do litej skały i mój rydel zwija się. Wtedy jestem skłonny rzec: „Po prostu tak właśnie postępuję” (Wittgenstein, 2008, ss. 123-124; Bourdieu, 2008, s. 35).

Bourdieu przywołuje Wittgensteina także w pierwszym rozdziale Zmysłu praktycznego, zatytułowanym „Zobiektywizować obiektywizację”. Celem tego rozdziału jest zaprezentowanie jednego bieguna antynomii teoretycznej między subiektywizmem a obiektywizmem. Wacquant podsumowuje:

Obiektywizm utrzymuje, że społeczna rzeczywistość składa się z sieci relacji i sił, które są narzucane działającym „niezależnie od ich świadomości i woli” (by przywołać znaną formuŁę Marksa). [...] Subiektywizm przeciwnie, za podstawowe uznaje indywidualne reprezentacje: wraz z Blumerem i Garfinklem oznajmia, że społeczna rzeczywistość jest sumą niezliczonych aktów interpretacji, w których ludzie wspólnie konstruują znaczące linie (inter)akcji (Wacquant, 1998, s. 220).

Przeciwnikami Wittgensteina (w konfiguracji zaproponowanej przez Bourdieu) są przede wszystkim: z jednej strony Ferdinand de Saussure i Claude Lévi-Strauss oraz marksizm Althussera, z drugiej - Jean-Paul Sartre, fenomenologia i inspirowane nią nurty socjologiczne (interakcjonizm symboliczny, etnometodologia). Między nimi zaś oscyluje tak zwana teoria działania racjonalnego (Rational Action Theory, z głównym przedstawicielem Jonem Elsterem) ${ }^{4}$. Dobór nazwisk nie jest systematyczny ani spójny i nieco zaskakujący zarówno dla socjologa, jak i filozofa. Uzasadnia go po części specyfika francuskiego pola intelektualnego i akademickiego, w którym Bourdieu wypracowywał swoją pozycję. Jak zauważa Szacki, we Francji od lat sześćdziesiątych obiektywistą najwybitniejszym i najbardziej wpływowym był Lévi-Strauss, a nie Talcott Parsons, subiektywistą zaś nie socjolog, ale cieszący się wręcz nieprawdopodobną popularnością Sartre (Szacki, 2002, s. 891).

Na początku rozdziału o obiektywizmie Bourdieu podejmuje kwestię języka. Najlepszym według niego sposobem na uchwycenie przesłanek obiektywizmu jest powrót do de Saussure’a. Utrzymując, iż prawdziwym medium komunikacji jest nie mowa (la parole), ale system językowy (la langue), „system obiektywnych relacji, umożliwiających zarówno produkcję wypowiedzi, jak i jej odszyfrowanie”, Bourdieu konstruuje język jako „logos przeciwstawiony praxis (a także oczywiście językowi praktykowanemu)" (Bourdieu, 2008, ss. 42, 43), martwy przedmiot analizy, iluzoryczny porządek. Mowę zaś redukuje do wykonania, którego - co charakterystyczne dla lingwistycznego i strukturalistycznego obiektywizmu - nie jest zdolny teoretycznie ująć.

Już tu widoczne są pokrewieństwa między Wittgensteinem a Bourdieu: obaj kwestionują takie obiektywistyczne stanowisko i zwracają uwagę na praktyczną stronę języka.

4 Jako postaci, które można umiejscowić pomiędzy tymi skrajnościami, choć z różnych powodów, wskazuje Bourdieu Georgesa Canguilhema i Maurice’a Merleau-Ponty'ego. 
Na odmienność koncepcji de Saussure’a i Wittgensteina wskazuje Schatzki, gdy zauważa, że metoda opisowa późnego Wittgensteina jest sprzeczna z większością strukturalistycznych analiz fenomenu komunikacji, zwłaszcza z

tezą Ferdinanda de Saussure’a, która mówi, że znaczenie pochodzi od abstrakcyjnych struktur różnic. Twierdzenie de Saussure’a, że znaczenie jest zakorzenione w nieprzestrzennej i nieczasowej sferze odrębnej od rzeczywistego mówienia i pisania, kłóci się z poglądem Wittgensteina, który sądzi, iż językowe znaczenie można uchwycić tylko dzięki szczegółowym opisom rzeczywistej aktywności (tzn. użyć języka, ich okoliczności oraz tego, co dzieje się podczas tych użyć) (Schatzki, 1996, s. 102).

Jak pokazuje Wittgenstein: „Wielką klasę przypadków, w których stosuje się słowo «znaczenie» - choć nie wszystkie jego zastosowania - można wyjaśnić tak: znaczeniem słowa jest sposób użycia go w języku” (Wittgenstein, 2008, s. 34)5. Alice Crary ostrzega nas, aby od „wielkiej klasy” nie przechodzić niepostrzeżenie do „wszystkich” przypadków i aby zważać na specyfikę filozofowania Wittgensteina. Wbrew temu bowiem, co się często uważa, Wittgenstein nie mówi, iż znaczeniem słowa jest jego użycie. Możliwe byłoby to jedynie przy przyjęciu zewnętrznej perspektywy wobec języka, którą to możliwość Wittgenstein odrzuca. Zdaniem Crary, choć „słuszne jest odczytywanie jego koncepcji [...] jako atakującej teorie, w których znaczenie ustala się niezależnie od wszelkiego użycia, to nie należy jednak przypisywać Wittgensteinowi poglądu,że użycie ustala znaczenie”, lecz jedynie taki, że „specyficzny rodzaj badania użycia jest istotny dla odpowiedzi na nasze pytania dotyczące znaczenia” (Crary, 2009, ss. 161, 169). Sądzę, że z tym powiązany jest jego sprzeciw wobec idei tworzenia innego, idealnego języka, odrębnego od języka potocznego: „może do tego, co chcemy powiedzieć, język ten jest zbyt gruby, zbyt materialny? Ale jak zatem tworzy się inny?" (Wittgenstein, 2008, s. 74) każe zastanowić się Wittgenstein.

Zarówno Bourdieu, jak Wittgenstein starają się wykryć powody, które skłaniają do ujmowania języka niezależnie od jego użycia. Zgadzają się w tym, że jedną z głównych przyczyn błędu intelektualistycznego jest sam język. W Zaproszeniu do socjologii refleksyjnej Bourdieu przyznaje, że język „stanowi dla socjologa problem szczególnie dramatyczny. Jest on de facto olbrzymim zbiorem pojęć przedustanowionych, które uległy naturalizacji [...] i działają jako nieświadome narzędzia konstrukcji” (Bourdieu \& Wacquant, 2001, s. 240), i przywołuje uwagę Wittgensteina: „Język zastawia na wszystkich takie same pułapki: potworną sieć łatwo dostępnych, błędnych dróg" (Bourdieu \& Wacquant, 1992, s. 241) $)^{6}$. Ale nie jest to przyczyna wyłączna. Wittgenstein także sugeruje, że wiele zamętu i pomyłek powstaje, kiedy ,język obraca się niejako na jałowym biegu, nie gdy

5 W Dociekaniach jeden z rozmówców wysuwa istotne wątpliwości względem tej „definicji” znaczenia, np. w paragrafie 138, co znaczące, w formie wykrzyknienia: „Jednakże znaczenie wyrazu ro z u m i e m y, gdy go słyszymy lub wypowiadamy; chwytamy je od razu, a tym, co tak chwytamy, jest przecież coś innego niż rozciągły w czasie użytek" (Wittgenstein, 2008, s. 81)

6 Zdania tego brak w polskim tłumaczeniu („Language sets everyone the same traps; it is an immense network of easily accessible wrong turnings"). Pochodzi ono z książki L. Wittgensteina, Culture and Value (Wittgenstein, 1980a, s. 18). W wersji polskojęzycznej: L. Wittgenstein, Uwagi różne (Wittgenstein, 2000, s. 127). 
pracuje" (Wittgenstein, 2008, s. 71). O ile jednak Wittgenstein nie koncentrował się na tej przyczynie przeteoretyzowanego stosunku do języka, o tyle Bourdieu podejmuje ten trop w wielu swoich książkach. Przykład koncepcji de Saussure’a pokazuje, przekonuje Bourdieu, że „ta typowo szkolna opozycja [między logos a praxis - M.P.P.] to wytwór sytuacji szkolnej, w mocnym sensie sytuacji skhole, otium, niedziałan ia", a więc teoretycznego dystansu tworzonego przez instytucje akademickie. Gramatyk, którym to terminem Bourdieu obejmuje badaczy popełniających błąd intelektualizmu względem języka, „milcząco skłonny jest traktować język jako autonomiczny i samowystarczalny przedmiot, czyli jako celowość bez celu, w każdym razie innego celu niż interpretowanie" (Bourdieu, 2008, ss. 43-44), tymczasem w większości przypadków język jest włączony w działanie, służy celom praktycznym.

Bourdieu interesuje nie tylko sam język, ale i jego funkcjonowanie w polu naukowym. Uwagi Wittgensteina o języku, postępowaniu według reguł czy rozumieniu interpretuje z perspektywy socjologicznej. Ponadto odnosi je nie tylko do praktyk językowych, ale praktyk w ogóle. Czy taki krok jest uzasadniony? Pociąga za sobą co najmniej dwa pytania. Po pierwsze, czy uwagi Wittgensteina stosują się do praktyk w ogóle. Po drugie kwestia ściśle z tym związana - czy kierowanie się regułami oraz rozumienie to według Wittgensteina zjawiska społeczne.

W ujęciu Bourdieu język u Wittgensteina ma nie tylko aspekt czy wymiar praktyczny, lecz podstawowy - sam język jest przede wszystkim praktyką w elementarnym, podwójnym sensie, który odnajdujemy u Bourdieu: jako wykonanie i zespół działań („przestrzenno-czasowy splot wykonań (spatial-temporal nexuses of doings)", jak to ujmuje Schatzki, 1997, s. 289). Interpretacja Bourdieu opiera się na spostrzeżeniu, że gdy autor Dociekań filozoficznych mówi o kierowaniu się regułami, nie ogranicza się do użycia języka, tylko podaje explicite przykłady robienia czegoś, działania (np. gra, budowanie, kierowanie się znakiem). Przykłady wydawania i wykonywania rozkazów czy zadań, nauczania i uczenia się podkreślają praktyczny status języka. Wiele innych uwag - o filozofach, którzy sądzą, że uchwycili istotę języka, znaczenia czy zdania, o iluzji pełności i jasności wyrażeń językowych, o grach językowych - pokazuje, że badanie języka powinno być nieoddzielne od badania praktyk czy też sposobów (form) życia. McGinn zauważa, że nacisk na praktyczne użycie języka, jego osadzenie w szeroko rozumianej ludzkiej aktywności, na ideę trenowania, uczenia się i praktycznego opanowywania języka jest „zdecydowanie centralny dla wizji języka, którą przedstawia nam Wittgenstein" (McGinn, 1997, s. 47). To, że używanie języka należy do praktycznych zdolności czy nawet jest praktyką pośród innych praktyk, wydaje się dziś rzadko kwestionowanym elementem wiedzy filozoficznej. Wittgenstein, wraz z pragmatystami, przyczynił się do wypracowania i rozpowszechnienia tego poglądu.

W odpowiedzi na drugie pytanie - o społeczny charakter praktyk - pomocne są rozważania Schatzkiego. Gdy Wittgenstein zastanawia się nad kwestią, czy kierować się regułą może jedna osoba raz w życiu, stwierdza, że zdaje się to niezgodne z "gramatyką zwrotu: «kierować się regułą»”: „Jest niemożliwością, by tylko jeden raz coś zakomunikowano, wydano jakiś rozkaz albo go zrozumiano itd." (Wittgenstein, 1998, ss. 118-119). 
Schatzki komentuje zwięźle i, jak sądzę, trafnie: „W zakres tego «itd.» [...] wchodzi działanie w ogóle. Każde działanie zakłada rozciągającą się w czasie (extended) praktykę" (Schatzki, 2000, s. 100). Autor książki Spoteczne praktyki. Wittgensteinowskie podejście do ludzkiej aktywności i tego, co społeczne przyznaje, że nie jest pewien, czy Wittgenstein "chciał zasugerować, że praktyki muszą mieć charakter społeczny”. Niemniej z jednej strony, przykłady podawane przez Wittgensteina zakładają powiązane ze sobą, zorganizowane w jakimś stopniu i skoordynowane zachowania wielu ludzi, a więc w tym sensie kontekst społeczny. Z drugiej strony, choć nie przywołuje on i nie opracowuje w sposób systematyczny oddziaływania społeczeństwa na ludzkie działanie, rozumienie i interpretowanie, podkreśla ważność okoliczności, kontekstu, otoczenia, czasem też używa pojęcia „sposobu życia” (Lebensform). Schatzki zauważa, że „niemieckie słowa, które w paragrafie 199 Wittgenstein wylicza, charakteryzując działanie - Gepflögenheiten, Gebräuche i Institutionen - to terminy zbiorowe. Żaden z nich nie oznacza czegoś, co może wykonać jedna osoba”. Wybór słów wskazuje, twierdzi dalej, że Wittgenstein uważał, iż praktyki mają charakter społeczny „przynajmniej faktycznie, jeśli także nie w teorii” (Schatzki, 2000, s. 101).

\section{„Kieruję się regutą, po prostu”}

Odsuwając na bok te podstawowe kwestie, wróćmy do interpretacji Wittgensteina i jej zastosowania przez Bourdieu, do czego także ustosunkował się Schatzki: „Bourdieu sugeruje, że jego ujęcie logiki praktycznej jest teorią praktycznego rozumienia w sensie, w jakim Wittgenstein mówi o rozumieniu jako umiejętności kontynuowania" (Schatzki, 1996, s. 150). Francuski socjolog wykorzystuje tezy, w myśl których używać języka i działać w ogóle to tyle, co „«opanować» pewną technikę (eine Technik «beherrschen»)" (Wittgenstein, 2008, s. 88), i rozwija temat kierowania się regułą po prostu, „bez racji” (Wittgenstein, 2008, s. 123). Jednakże nie jest całkiem oczywiste, co oznacza owo „bez racji”.

Zdaniem Charlesa Taylora, który także dostrzega podobieństwa i nawiązania Bourdieu do Wittgensteina w teorii praktyki, istnieją dwie szkoły interpretacji tego sformułowania, którym odpowiadają dwa sposoby rozumienia tego, co określa on jako „niewyartykułowane podłoże" (Taylor, 1993, s. 48). Pierwsza utrzymuje, że nie można podać żadnych racji postępowania, a powiązania tworzące kulturowe podłoże to relacje de facto. To stanowisko można oprzeć na uwagach Wittgensteina, że „gdy kieruję się regułą, to nie wybieram. Kieruję się nią śl e p o”, „ «Po prostu tak właśnie postępuję»” (Wittgenstein, 2008, s. 125). Taylor zalicza do tych teorii sceptyczną interpretację kierowania się regułą Saula Kripkego. Z rozważań zawartych w książce Kripkego Wittgenstein o regułach i języku prywatnym wyciągano wniosek, że pierwszą część paragrafu 201 można uznać za konkluzję Dociekań7: „Paradoks nasz wygląda tak: reguła nie może wyznaczać sposobu działania,

7 David Finkelstein (2009, s. 86) uważa, że takiej „konkluzji” zaprzecza tok myślenia przedstawiony w drugiej części tego paragrafu (zacytowanej u niego z pominięciem dwóch ostatnich zdań): „Że jest to nieporozumienie widać już stąd, że w rozumowaniu tym podajemy interpretację za interpretacją; jak gdyby każda zadowalała nas na chwilę, dopóki nie pomyślimy o następnej. Albowiem wykazujemy w ten sposób, że istnieje takie ujęcie reguły, które nie jest interpretacją. Przejawia się ono od przypadku do przypadku w tym, co nazywamy «kierowaniem się regułą» oraz «postępowaniem wbrew niej»" (Wittgenstein, 2008, ss. 119-120). 
gdyż każdy sposób działania daje się z nią uzgodnić. A odpowiedź brzmiała: jeżeli każdy sposób działania można uzgodnić z regułą, to każdy można też doprowadzić z nią do sprzeczności" (Wittgenstein, 2008, s. 120). Rozważając ten paradoks w odniesieniu do znaczenia, Kripke konkluduje, że jeśli dobrze rozumie Wittgensteina, według autora Dociekań żadne fakty nie określają tego, co znaczą nasze słowa (niezależnie od tego, czy są tylko pomyślane, czy napisane lub wypowiedziane), albo raczej, iż Wittgenstein uważa, że „negatywne tezy sceptyka nie mogą być odrzucone” (Kripke, 2007, s. 111).

Druga interpretacja wedle Taylora opiera się na krytyce intelektualizmu i poglądu, że kierowanie się regułą wymaga obecności w umyśle jej przedstawienia. Niewyartykułowane podłoże zawiera pewne rozumienie, które „zezwala nam na formułowanie wyjaśnień i podawanie racji, gdy ktoś tego zażąda" (Taylor, 1993, s. 48) - zawiera sens, choć nie zawsze jest on jasny dla osoby działającej. Taylor sądzi, że to drugie stanowisko jest bliższe temu, co chciał przekazać autor Dociekań filozoficznych. Wraz z Heideggerem czy Merleau-Pontym Wittgenstein umieszcza „pierwotne locus rozumienia w praktyce” (Taylor, 1993, s. 49). Taylor zgadza się w tym z Bourdieu i z pism Wittgensteina wyciąga wniosek, że gdy zmniejsza się rolę reprezentacji w zachowaniu, większego znaczenia nabiera rola zachowań cielesnych. Nie chodzi mu rzecz jasna o ciało pojęte behawiorystycznie. Skoro możemy kierować się regułą i działać poprawnie, nie posiadając w umyśle idei czy przedstawienia reguły, które uzasadniałyby nasze zachowanie czy nim kierowały, argumentuje Taylor, trzeba porzucić intelektualistyczny pogląd na rozumienie i wprowadzić koncepcję „rozumienia wcielonego” (Taylor, 1993, s. 53). Schatzki także utrzymuje, że „według Wittgensteina wszystkie ludzkie działania i myśli mają u swych podstaw repertuar niekognitywnych [...] zdolności używania cielesnej performatywności” (Schatzki, 1996, s. 51).

W paragrafie 198 Wittgenstein czy raczej rozmówcy toczący dialog na kartach Dociekań próbują określić relację między działaniem a jego racjami. Jeden z nich stwierdza, że powiązanie powstaje wskutek „ćwiczenia”, ale drugi odpowiada: „w ten sposób podałeś tylko związek przyczynowy, wyjaśniłeś jedynie, jak to się stało, że kierujemy się obecnie drogowskazem, nie zaś na czym właściwie owo kierowanie-się-znakiem polega" (Wittgenstein, 2008, s. 118). Drugi rozmówca szuka więc czegoś więcej niż „związek przyczynowy”. Jak twierdzi Taylor, to intelektualizm popada w rozumienie „reguły-jako-reprezentacji (a rule-as-represented) jako w pewien sposób działającej przyczynowo” (Taylor, 1993, s. 55). Wittgenstein pokazuje zaś, że bardzo problematyczny jest pogląd, iż kierowanie się regułą i rozumienie znaczenia jest zależne od stanów mentalnych, które miałyby być przyczyną danego działania. Gdy coś rozumiemy, na przykład formułę matematyczną czy znaczenie słowa, czy znaczy to, że antycypujemy bądź mamy w umyśle wszystkie ich użycia? Czy możemy uchwycić stany psychiczne, „które zdają się kryć za prostszymi i stąd łatwiej rzucającymi się w oczy zjawiskami towarzyszącymi” (Wittgenstein, 2008, s. 90)? Wittgenstein nie rezygnuje ostatecznie z idei, że jakieś psychiczne stany towarzyszą rozumieniu, jednak jego gramatyczne dociekanie wskazuje, iż lepiej „nie myśleć o rozumieniu jako o «zjawisku psychicznym». Myli cię bowiem te n właśnie sposób mówienia” 
(Wittgenstein, 2008, s. 91). Stoi on raczej po stronie pierwszego z rozmówców, który odrzuca zarzut, iż mówiąc o „ćwiczeniu”, podał związek przyczynowy: „Nie; zaznaczyłem też, że tylko o tyle ktoś kieruje się drogowskazem, o ile istnieje tu stały nawyk, stały zwyczaj" (Wittgenstein, 2008, s. 118).

Taylor uważa, że reguły u Bourdieu nie są podstawą przyczynowych regularności; to raczej „wzory uzasadniania działan” (Taylor, 1993, s. 58) ${ }^{8}$. Sądzi też, że obaj autorzy używają pojęcia reguły, które ma cechować elastyczność i które sytuuje się we wzajemnie dynamicznej relacji do praktyki: „Między formułą i jej zastosowaniem jest pewna fronetyczna przepaść (phronetic gap)”, „praktyka nie tylko wypełnia regułę, ale także nadaje jej określony kształt w poszczególnych sytuacjach" (Taylor, 1993, s. 57) - stwierdza Taylor, nawiązując do miejsc, w których jego zdaniem Wittgenstein i Bourdieu mówią jednym głosem.

Kwestia tego, czy i w jaki sposób reguła miałaby wyznaczać swoje zastosowania, jest bardzo częstym tematem rozważań komentatorów Dociekań. Zdaniem Finkelsteina wielu czytelników Wittgensteina (do których zaliczyć można by Taylora) popełnia błąd, uznając, iż autor przyjmuje stanowisko interlokutora stwierdzającego,że między regułą a wykonaniem znajduje się przepaść („Między rozkazem i wykonaniem go leży przepaść. Wypełnić ją musi rozumienie”; Wittgenstein, 2008, s. 182). Większość reguł, którymi się kierujemy, przekonuje Finkelstein, nie stwarza problemów, jakie wyobrażają sobie tylko filozofowie, nie wymaga zatem interpretacji ${ }^{9}$. Metafory i pojęcia Wittgensteinowskie, takie jak forma życia, dywan życia, praktyka, nie są kandydatami na wypełnienie luki między regułą a jej zastosowaniem:

$\mathrm{Nie}$ chodzi o to, że „dywan życia” (nasze zwyczaje i instytucje) zamiast dookreślenia lub interpretacji wypełnia przepaść między stwierdzeniem reguły a wykonaniem jej rozkazu. Lepiej byłoby powiedzieć, że kiedy postrzegamy reguły jako usytuowane wewnątrz naszego życia, takie przepaście są rzeczą wyjątkową (Finkelstein, 2009, s. 92).

To pogląd w zasadzie nieodległy od stanowiska Taylora (reguła nie musi być interpretowana, aby wcielać ją w życie), lecz nieco od niego odmienny (ponieważ reguły dla podmiotów działających są zazwyczaj oczywiste, między nimi a ich wykonaniem nie ma „luki” czy „przepaści”, jest natomiast pewien automatyzm czy, jak mówi Finkelstein, „autonomia").

8 Nie spotkałam się z takim sformułowaniem u samego Bourdieu. Stanowisko Jacquesa Bouvresse wydaje się być zbliżone do ujęcia Taylora: „Wiedzieć, jak zastosować regułę, znaczy w wielu wypadkach posiadać zdolność je interpretacji w określonych warunkach, a nawet wiedzę o tym, jak ją zignorować czy złamać inteligentnie" (Bouvresse, 1999, s. 55).

9 „Podawanie interpretacji zdania (lub drogowskazu) ma sens wtedy, kiedy ktoś je źle zrozumiał albo kiedy istnieje realne zagrożenie, że źle rozumie. I tutaj jest właściwe miejsce interpretacji. Jednak kiedy uprawiamy filozofię, dochodzimy do przekonania, że interpretacja wymagana jest wszędzie, gdziekolwiek możemy sobie wyobrazic nieporozumienie" (Finkelstein, 2009, s. 88). Podobnie stawia ten problem Martin Stone. Jego zdaniem wiele filozoficznych trudności pojawia się, gdy porzucamy codzienną formę słów i rozważamy na przykład, jak może oznaczać „znak sam w sobie” (Stone, 2009). 


\section{Czy zachować „regutę”?}

Schatzki z uwag Wittgensteina o postępowaniu według reguł wyciąga wniosek, że pojęcie reguły, przynajmniej w odniesieniu do rozumienia znaczenia, „raczej wprowadza w błąd, niż coś objaśnia. Lepiej porzucić ideę, iż reguły i znaczenia determinują użycie językowe, aby przyszłej refleksji przewodziła idea niesformułowanego rozumienia (unformulable understandings)" (Schatzki, 1996, s. 51) ${ }^{10}$. Reguły służą tylko opisowi działania ex post facto. Wnioski te wyciąga Schatzki, chociaż „różne fragmenty w późnych pismach Wittgensteina sugerują, że filozof postrzega język jako kierowany regułami i nie kierowany regułami” (Schatzki, 1996, s. 50). „KKierowanie się regułą» jest pewną praktyką” czytamy w paragrafie 202 (Wittgenstein, 2008, s. 120). Uwagę tę mogliby przytoczyć na poparcie swojej tezy i Taylor, i Schatzki. Czy Wittgenstein chce powiedzieć, że działania (nie tylko językowego) nie można rozbijać na reguły, choć można je w drodze analizy odnaleźć, „wydestylować” z zachowania i/lub opisać zachowanie przy ich użyciu? Lub że reguły są nieco automatycznie czy nawykowo wcielane w życie, a ich świadomość jest niewyraźna lub niepełna, lecz w razie potrzeby można je przywołać? Czy ma na myśli jeszcze coś innego? Sam Wittgenstein zasłynął między innymi tym, że zwrócił uwagę na wieloznaczność pojęcia „reguła” i jego zastosowania w analizach teoretycznych. Bouvresse twierdzi nawet, że jeśli jest coś, co łączy Wittgensteina i Bourdieu, to jest to właśnie świadomość wieloznaczności tego pojęcia, a raczej wielości sposobów, w jakie się go używa.

Pogląd, iż działanie polega na kierowaniu się regułami, stwierdza Bourdieu, to jeden z najbardziej narzucających się i rozpowszechnionych elementów teorii praktyk zarówno naukowych ${ }^{11}$, jak i zdroworozsądkowych, spontanicznych, „tubylczych”. Bourdieu kwestionuje go, odwołując się w kluczowym momencie argumentacji do znanego fragmentu z Wittgensteina:

Co nazywam „regułą, do której on się stosuje”? - Hipotezę opisującą w zadowalający sposób obserwowane przez nas u niego użycie słów? Albo regułę odszukiwaną przezeń w książce? Albo może tę, którą otrzymamy, spytawszy go o jego regułę? - Cóż jednak, gdy obserwacja nie pozwala jasno rozpoznać żadnej reguły, a pytanie też jej nie ujawnia? [...] Albo lepiej: cóż jeszcze miałby tu znaczyć zwrot: „Reguła, do której on się stosuje”? (Wittgenstein, 2008, s. 60).

Bourdieu zgadza się, iż pojęcie reguły jest wieloznaczne. W wywiadzie zatytułowanym From rules to strategies wymienia trzy jego rozumienia:

1) zasada prawna czy quasi-prawna, mniej lub bardziej świadomie wytworzona i opanowana przez podmiot działający;

10 Na ich potwierdzenie przywołuje Schatzki paragraf 82 Dociekań (Wittgenstein, 2008, s. 60), cytowany także przez Bourdieu.

11 Szczególną uwagę Bourdieu poświęcił niespójnościom w ujmowaniu reguły przez antropologię strukturalną Lévi-Straussa i niezdolności zmierzenia się przez nią z problemem regularności.

SLH 6/2017 | str. 10 z 25 
2) zbiór obiektywnych regularności narzucanych wszystkim, którzy przyłączą się do danej gry społecznej;

3) model czy zasada skonstruowana przez naukowca, by wyjaśnić praktykę (Bourdieu, 1990, ss. $60-61)^{12}$.

Często myli się te rozumienia, biorąc na przykład obserwowaną regularność za zbiór reguł, którymi kierują się działający. Bourdieu nie rezygnuje z „regularności”, ale unika pojęć takich, jak reguła, regulacja, wzór, kierowanie się regułą itd. W ujęciu Taylora „Antropologia, jak każda inna nauka społeczna, nie może nie posiadać jakiegoś pojęcia reguły" (Taylor, 1993, s. 54), lecz Bourdieu, jak sądzę, nie zgodziłby się z tą oceną. Wypracował on teorię praktyki, która miała nie tyle przedefiniować pojęcie reguły, ile uniknąć myślenia o praktyce w terminach regut. Swą awersję do „regut” tak wyrażał w Zmyśle praktycznym: „Obiektywne dopasowanie dyspozycji i struktur zapewnia zgodność z obiektywnymi warunkami i pilnymi zadaniami, która nie ma nic wspólnego z regułą i świadomą zgodnością z regułą" (Bourdieu, 2008, s. 197) ${ }^{13}$. Niemniej mimo prób wykreślenia "reguły” ze słownika nauk społecznych autor Zmysłu praktycznego uważa za konieczne wprowadzenie ograniczonego rozumienia tego pojęcia do teorii praktyki, ponieważ reguły funkcjonują w rzeczywistości społecznej, gdy ulegają kodyfikacji i stanowią część zjawiska nazywanego przez niego „oficjalizacją".

Gdy zakwestionujemy stanowisko, według którego działania opierają się na świadomym kierowaniu się regułami, pozostaje problem wyjaśnienia regularności naszych codziennych działań, także na poziomie zbiorowości (poziomie makro), i faktu, iż niektóre działania są postrzegane jako wykonane poprawnie, a inne nie ${ }^{14}$. Sądzę, że problem działania według reguł jest $\mathrm{w}$ dziele Bourdieu ściśle związany z zagadnieniem świadomego działania w ogóle i refleksyjności podmiotów działających, niekiedy nawet problemy te płynnie w siebie przechodzą. Bourdieu krytykuje obiektywizm, który, by wyjaśnić działanie, musi odwoływać się do reguł i myli model rzeczywistości z rzeczywistością, dystansuje się też od subiektywizmu, który u podstaw działania widzi cele, zamiary, projekty, przemyślenia i racjonalne argumenty, świadome kierowanie się regułami, normami, wartościami czy korzyściami.

12 Podobne rozróżnienie pojawia się już w Zmyśle praktycznym. Odnosząc się do koncepcji Chomsky’ego, Bourdieu twierdzi, że „reguła” w różnych użyciach znaczy „immanentną regularność praktyk”, „m o del skon st ru owa ny przez naukę", by ją wyjaśnić, bądź normę świadomie ustanowioną i przestrzeganą przez podmioty działające (Bourdieu, 2008, s. 50).

13 Wyróżnienie moje. Później Bourdieu zaznacza, że automatyzm habitusu czyni reguły zbędnymi, gdy warunki jego kształtowania nie zmieniają się lub zmieniają nieznacznie: „Paradoksalnie więc nauki społeczne nigdy nie sięgają po język reguły tak często, jak wtedy, gdy jest on zupełnie nieodpowiedni, czyli w analizie formacji społecznych, gdy z racji stałości obiektywnych warunków w czasie udział reguły w rzeczywistym określaniu praktyk jest szczególnie ograniczony, a zasadnicza rola przypada automatyzmom habitusu” (Bourdieu, 2008, s. 197).

14 Tak sądzi na przykład Peter Winch: „Sprawdzianem tego, czy człowiek stosuje w swoich działaniach regułę, nie jest zdolność do sformułowania jej, ale to, czy w odniesieniu do jego działania da się sensownie odróżnić właściwy i błędny sposób robienia rzeczy" (Winch, 1995, s. 64). Anthony Giddens przywołuje wątpliwość Alasdaire’a McIntyre’a: czy jest w takim razie właściwy i niewłaściwy sposób pójścia na spacer? Mclntyre sądzi, że nie, natomiast Giddens, choć krytycznie nastawiony względem Wincha, stwierdza, że z jednej strony można oceniać, czy wyrażenie „pójście na spacer” jest prawidłowo używane, z drugiej - poddać jakiś sposób spacerowania (np. spacer po autostradzie) moralno-obyczajowej ocenie i ewentualnym sankcjom (Giddens, 2009, s. 43). 
Bourdieu czyni to, wypracowując koncepcję habitusu. Jest ona kluczowa dla jego socjologii, a w szczególności dla jej podstawowej części, którą określa się jako teorię praktyki.Zgodnie z założeniami habitus ma wymykać się dualizmom, takim jak subiektywizm - obiektywizm, świadomość - nieświadomość, działanie wolne - działanie zdeterminowane, ciało - umyst, materializm - idealizm, a także strukturalizm - filozofia podmiotu, i uchwycić rolę ciała w poznaniu i działaniu. Ma zatem być także odpowiedzią na pytania, które dręczyły Wittgensteina (słowami Bourdieu - na problem „praktykowania praktyki”). W tym kontekście interesująca jest deklaracja Bourdieu dotycząca pojęcia habitusu: „habitus [...] ma wartość być może głównie ze względu na fałszywe problemy i fałszywe rozwiązania, które eliminuje, pytania, które pozwala lepiej sformułować, i ściśle naukowe trudności, które dzięki niemu wychodzą na jaw" (Bourdieu, 2008, s. 87). Czy nie jest to motywacja iście wittgensteinowska w swoim nakierowaniu na wyeliminowanie nieporozumień, błędnych interpretacji i fałszywych poglądów na ludzką praktykę? Wszak Wittgenstein przyznawał, że „Filozofia może jedynie obalać fałszywych bogów” (Wittgenstein, 1991, s. 171), co zdaniem jednego z jego komentatorów oznacza, że przeciwstawia się ona iluzjom i winna wskazywać „drogę wyjścia z jaskini fundamentalnego złudzenia" (Stone, 2009, s. 138).

Kontrowersje towarzyszą jednak samemu rozstrzygnięciu pytania o to, czy reguła i ewentualnie jak rozumiana jest zdaniem Wittgensteina nieodzowna do adekwatnego ujęcia działania i praktyki. Zdaniem francuskiego socjologa Wittgenstein pokazuje, iż działanie nie opiera się na postępowaniu zgodnym z przedstawieniem reguły obecnym w umyśle, jej rozumieniu czy interpretacji, więc musi istnieć „takie ujęcie reguły, które nie jest interpretacją" (Wittgenstein, 2008, s. 119). Ten rys praktyki dobrze można oddać, odwołując się do fragmentów pism Wittgensteina zawierających pojęcia „opanowania” (herrschen) (języka, techniki), ,instytucji”, ,zwyczaju”, ,ćwiczenia”, ,regularnego użycia” czy przykłady, w których prezentuje praktyczne, konkretne sytuacje rozwiązywane w praktyczny sposób. Krytyka mentalizmu i intelektualizmu zdaje się wspierać te usiłowania.

Niektórzy są jednak bardziej wstrzemięźliwi niż Bourdieu w opowiadaniu się za regułami lub przeciw nim. Bouvresse komentuje stanowisko autora Dociekań następująco: „Wittgenstein rzadko coś kategorycznie wyklucza - czy to pojęcie nieświadomej normy, czy inne. Dla niego ważne jest zdawanie sobie sprawy z tego, co się robi, gdy używa się konkretnego słowa lub ekspresji” (Bouvresse, 1999, s. 55). Bourdieu natomiast wyklucza pojęcie nieświadomej normy w proponowanej przez siebie oryginalnej teorii praktyki, narażając się tym kategorycznym krokiem, którego, jak sugeruje Bouvresse, nie zrobił Wittgenstein, na liczne i ostre krytyki. Jednakże ze względu na to, iż problem interpretacji Wittgensteina przez Bourdieu jest podejmowany często, a zarazem w sposób wiele mówiący o interesującej mnie teorii socjologicznej, przedstawię jeszcze wybrane krytyki Bourdieu, których autorzy uważają, iż w swych rozważaniach są wierniejsi intuicjom austriackiego filozofa. 


\section{Reguty i interesy}

Bourdieu sądzi, że dzięki pojęciom habitusu i strategii można wyrugować skłonność do legalizmu, którą przejawiają etnolodzy podejmujący badania wymian darów, systemów pokrewieństwa, systemów klasyfikacyjnych, zachowań honorowych i wielu innych. $Z$ tą intencją kwestionuje powszechnie znaną badaczom plemion berberyjskich reguŁę, wedle której mężczyzna ma prawo do kuzynki równoległej. Po pierwsze, stwierdza Bourdieu, po bliższej analizie prawo to okazuje się raczej obowiązkiem (w dodatku pojawiającym się w rzadkich i wyjątkowych okolicznościach), przypominającym obowiązki „pomszczenia członka rodziny lub odkupienia ziemi należącej do rodziny, na którą ostrzą sobie zęby obcy" (Bourdieu, 2007, s. 237). Reguła ta jest uruchamiana przede wszystkim wtedy, gdy kuzynka równoległa ma trudności ze znalezieniem męża. Po drugie, siła obowiązywania powinności, jej kategoryczność „zależy od pozycji w genealogii i oczywiście dyspozycji działających podmiotów" (Bourdieu, 2007, s. 237). Bourdieu powtarza za Kabylami „ "Każda reguła ma furtkę»”. Niektórzy mogą stosować uniki, jednakże w przypadku innych, zwłaszcza najbiedniejszych członków rodziny, taka strategia jest wykluczona. Istotne jest też, kto prosi o rękę dziewczyny (starszy czy młodszy brat, brat bogatszy dla swoich synów, stryj o bratanicę dla kogoś, wobec kogo zaciągnął zobowiązanie) ${ }^{15}$. Nierzadkie są również odstępstwa od zasady, która mówi, że mężczyzna prosi o żonę: ojciec może proponować córkę bratankowi (o ile istnieją silne więzi między braćmi), a wówczas odmowa małżeństwa jest raczej niemożliwa.

Zatem zdaniem Bourdieu badanie pokrewieństwa nie może ograniczać się do rozrysowywania genealogicznych porządków określanych przez zasadę pokrewieństwa ani do katalogowania zbiorów reguł przywoływanych przez tubylców. Jego badania wykazały nawet, że „W praktyce owo idealne małżeństwo to często wybór przymusowy i niekiedy pojawiają się starania, by przedstawić je jako wybór idealny, czyniący z konieczności cnotę" (Bourdieu, 2008, s. 243). W podobnych badaniach, postuluje Bourdieu, trzeba uwzględnić materialne i symboliczne położenie rodziny, jej historię, interesy poszczególnych członków związane z płcią, wiekiem czy autorytetem oraz ogół możliwych małżeństw. Ponadto nie można rozpatrywać strategii matrymonialnych w oderwaniu od innych strategii - edukacyjnych, ekonomicznych itd. - służących biologicznej i spoŁecznej reprodukcji rodziny (Bourdieu, 1990, s. 68). Stosunek między drzewami genealogicznymi a rzeczywistymi relacjami pokrewieństwa, zwłaszcza w społeczeństwach niepiśmiennych, jest taki, jak między mapą możliwych, ale niekoniecznie używanych dróg, którą można objąć jednym spojrzeniem i śledzić w dowolnym kierunku, a rzeczywiście używaną, przecieraną i udeptywaną w niejednakowym stopniu siecią ścieżek (Bourdieu, 2002, s. 137).

15 Różna jest kategoryczność analogicznych jakoby powinności i zależy ona od tego, czy w grę wchodzi obowiązek zemsty, wykupu ziemi czy też małżeństwa. 


\section{Oficjalizacja}

Jak wspomniałam, autor Dystynkcji nie zamierza całkowicie wykluczać pojęcia reguły z teorii praktyki, ponieważ funkcjonuje ono w społecznej rzeczywistości, zwłaszcza jako element procesu „oficjalizacji”, czyli procesu, dzięki któremu

grupa (lub ci, którzy w niej dominują) poznaje i ukrywa przed sobą własną prawdę, tącząc się między sobą za sprawą publicznego wyznania, które dopuszcza i narzuca to, co głosi, oraz niejawnie określa granice tego, co możliwe do pomyślenia, a co nie, przyczyniając się w ten sposób do utrzymania porządku społecznego, z którego czerpie swą władzę (Bourdieu, 2008, s. 147).

Autor tych słów zdaje się przesądzać, że grupa lub jej dominujące frakcje mają zawsze coś do ukrycia, przede wszystkim przed sobą. Za zachowaniami kryją się inne motywacje czy determinacje niż te deklarowane. Warto zacytować dłuższy fragment:

Strategiom bezpośrednio nastawionym na podstawowy zysk [...] często towarzyszą strategie drugiego stopnia, dążące do pozornego zadowolenia wymogów oficjalnej reguły, a dzięki temu do skumulowania zaspokojenia zysku oraz prestiżu i szacunku, co niemal powszechnie obiecują działania pozornie niemające innego celu niż poszanowanie reguły. W istocie grupy niczego bardziej nie pragną i niczego nie nagradzają tak szczodrze, jak poważania jawnie okazywanego temu, co same obdarzają czcią (Bourdieu, 2008, ss. 147-148).

Po pierwsze zatem, interes (intérêt) jest podstawową, choć raczej nieuświadamianą przyczyną działania. Bourdieu stwierdza to wprost: „Nie musimy chyba przypominać za Weberem, że reguła prawna lub zwyczajowa jest zawsze jedynie drugorzędną zasadą determinowania praktyk, dochodzącą do głosu zastępczo i tylko wtedy, gdy brak zasady podstawowej, tzn. interesu (subiektywnego lub obiektywnego)" (Bourdieu, 2007, s. 235). Po drugie, grupie w gruncie rzeczy nie zależy na tym, by jej członkowie przestrzegali regut, które oficjalnie głoszą. Wystarczy jedynie, by zachowywali pozory, iż kierują się jej kodeksem, by okazywali grupie pozorne posłuszeństwo:

W pewnym sensie, to znaczy z punktu widzenia grupy, nie ma nic bardziej pobożnego niż „pobożne kłamstwa”, „bogobojna hipokryzja”. Jeśli grupy tak łatwo akceptują oszustwa, [...] to dlatego, że zawierają one niewątpliwą deklarację szacunku dla grupowej reguły (Bourdieu, 2009, s. 175).

Dzięki takim strategiom interes prywatny, egoistyczny uzyskuje szlachetniejszą formę interesu publicznego, zbiorowego, prawomocnego, uniwersalnego.

Jednakże, omawiając zjawisko oficjalizacji, Bourdieu przeprowadza rozumowanie, które, jak się zdaje, nie jest do końca spójne z kategorycznym wykluczeniem regut jako zasad w znaczącym stopniu determinujących działanie. W odniesieniu do tego, co Berger i Luckmann nazywają „wiedzą o charakterze przepisu” - przedteoretyczną, 
pierwotną wiedzą o porządku społecznym (Berger \& Luckmann, 1983, s. 112) ${ }^{16}$ stwierdza:

Oficjalne wyobrażenia, do których obok reguł zwyczajowych należy dodać wiersze gnomiczne, powiedzenia bądź przysłowia, wszelkie rodzaje obiektywizacji schematów postrzegania i działania w słowach, rzeczach lub praktykach [...], utrzymują dialektyczną relację z dyspozycjami, które się w nich wyrażają, przyczyniając się do ich wytwarzania i wzmacniania (Bourdieu, 2008, s. 146).

Wydaje się, że jeśli relacja jest dialektyczna, reguły przyczyniają się do „wytwarzania i wzmacniania" dyspozycji, a jeżeli obiektywizacje reguł są choć częściowo poprawne, aktorzy społeczni rzeczywiście działają według (przynajmniej części) reguł, które ujmują w słowa lub rytuały i do których potrafią się refleksyjnie ustosunkowywać.

W Szkicu teorii praktyki zamiast o „relacji dialektycznej” Bourdieu mówi o nakładaniu się oficjalnych reguł na dyspozycje habitusu: „W Kabylii reguły prawa zwyczajowego o tyle mają jakąś skuteczność praktyczną, o ile, podlegając zręcznym manipulacjom ze strony osób sprawujących władzę w klanie, nakładają się na kolektywne dyspozycje habitusu i je wzmacniają" (Bourdieu, 2007, s. 234) ${ }^{17}$. Oczywiście autor Rozumu praktycznego kazałby w tym momencie wrócić co najmniej do argumentów i przykładów z poprzedniego akapitu. Zwróciłby też, jak mogę przypuszczać, uwagę na to, że za oficjalizację są odpowiedzialne zwykle grupy dominujące, a ponadto podlegają jej reguły najbardziej w ich ocenie chlubne i emblematyczne.

Trzeba jeszcze powiedzieć o innej funkcji, jaką Bourdieu przypisuje regułom, zwłaszcza skodyfikowanym ${ }^{18}$. Jest to funkcja minimalizowania niejednoznaczności i ambiwalencji zachowań oraz zapobiegania potencjalnym konfliktom. Chodzi tu zwłaszcza o sytuacje interakcji między wrogimi lub obcymi sobie grupami, szczególnie w momentach zagrożenia, niepewności czy konfliktu. Bourdieu stwierdza następującą prawidłowość: stopień kodyfikacji jest proporcjonalny do ryzyka. Badania w Kabylii pokazały, że w przypadku małżeństw członków grup odległych, a więc związków prestiżowych,

większy będzie zysk symboliczny, ale także większe ryzyko. To w tym przypadku mamy do czynienia z wysokim stopniem formalizacji praktyk; także tutaj reguły grzeczności będą najbardziej wyszukane, a rytuały szczegółowo rozplanowane (Bourdieu, 1990, s. 78).

16 Pojęcie recipe knowledge autorzy zaczerpnęli od Alfreda Schütza.

17 Druga część tego zdania brzmi: „tylko różnice stopnia dzielą je więc od cząstkowych i nierzadko wymyślonych sformułowań zasad praktyki, które służą jedynie zaradzeniu niedostatkom i niejednoznacznościom habitusu, podając rozwiązania dostosowane do trudnych sytuacji”. 0 tej funkcji reguł $w$ dalszej partii mojego tekstu.

18 Wysoki stopień kodyfikacji występuje zazwyczaj w społeczeństwach zróżnicowanych: „Kodyfikacja jest operacją symbolicznego porządkowania czy utrzymywania symbolicznego porządku, które to zadanie najczęściej wypełniają państwowe biurokracje” (Bourdieu, 1990, s. 80). Wiąże się ona z normalizacją (którą Bourdieu określa też jako „efekt narzucenia symbolicznego”) i dyscyplinowaniem. Np. skodyfikowanie reguł gramatycznych, wzmocnione przez działanie instytucji szkoły, powoduje, że posługiwanie się językiem poprawnym - prawomocnym jest narzucone i wymagane od wszystkich grup społecznych, niezależnie od rzeczywistych możliwości i szans osiągnięcia takiego opanowania. Natomiast tam, gdzie mamy do czynienia z niskim stopniem kodyfikacji, bardziej liczy się zmysł gry i zdolności improwizacji. 


\section{Dalej Bourdieu uogólnia tę myśl:}

Im bardziej sytuacja jest brzemienna w potencjalną przemoc, tym bardziej ludzie muszą respektować konwencje, tym bardziej zachowanie powierzone improwizującemu habitusowi [freely vested in the improvisation of the habitus] ustąpi zachowaniu bezpośrednio determinowanemu przez metodycznie zinstytucjonalizowany, nawet skodyfikowany ry tuat (Bourdieu, 1990, s. 78).

Widać więc jasno, że skoro oficjalne reguły mogą zaradzać niejednoznacznościom i zapobiegać konfliktom, są istotną determinantą przynajmniej niektórych praktyk, co, przyznajmy, nie wyklucza tego, że ich poszanowaniu towarzyszy działanie na rzecz jakiegoś interesu. Nie unieważnia to także wniosku, który wynika z rozważań Wittgensteina: nie wiadomo, czym jest „poprawne zastosowanie reguły”, które miałoby być wcześniejsze i niezależne od regularnej praktyki jej stosowania. Sformułowanie to nie ma znaczenia poza takim rodzajem praktyki (Bouvresse, 1999, s. 57).

\section{Giddens - struktura(cja) i reguty}

Problem reguł w relacji do praktyki inaczej rozwiązuje Anthony Giddens, który za swojego przewodnika w tej kłopotliwej dziedzinie również obrał Wittgensteina. Tak jak Bourdieu Giddens artykułuje własną pozycję jako trzecią drogę między obiektywizmem a subiektywizmem w naukach społecznych. Dla jego teorii praktyki kluczowe jest pojęcie struktury rozumianej jako zbiór reguł i zasobów. Autor Stanowienia społeczeństwa przestrzega przed traktowaniem jej jako autonomicznego bytu, jest ona bowiem rezultatem sedymentacji praktyk i aktualizuje się tylko w procesie strukturacji. Struktura, w elementarnym sensie, jest zbiorem reguł i zasobów uczestniczących w reprodukcji systemów społecznych. Giddens wyróżnia dwojakiego rodzaju zasoby, czyli czynniki generujące władzę w danym społeczeństwie: zasoby alokacji (czy alokacyjne) i autorytetu. Pierwsze są materialne i odnoszą się do sfery przedmiotów stworzonych oraz świata naturalnego, drugie - niematerialne - obejmują ludzką wiedzę i zdolności. Reguły są drugim składnikiem struktur. Giddens zdaje sobie sprawę, że jest to pojęcie problematyczne, niemniej uznaje je za niezbędne i wyjaśniając szczegółowo swoje inspirowane Wittgensteinem rozumienie regut, podaje ku temu powody. Czym są reguły? Dla autora Nowoczesności i tożsamości to aspekty praxis, a dokładniej „techniki czy też uogólnione procedury stosowane w ustanawianiu/odtwarzaniu praktyk społecznych" (Giddens, 2003, s. 60). Reguły tak szeroko rozumiane autor Stanowienia społeczeństwa odróżnia od ich podtypu - reguł skodyfikowanych (kanonów prawa, reguł gier itd.), które są właściwie skodyfikowanymi interpretacjami reguł.

Nawet jeśli da się je ująć we wzór (jak podawane przez Wittgensteina wzory matematyczne), rozumienie reguł polega na umiejętności ich stosowania we właściwy sposób i we właściwej sytuacji. Często trudno z góry precyzyjnie ocenić, która sytuacja jest właściwa, czasem też sposobów użycia jednej reguły może być więcej, stąd jej określenie jako „procedury uogólnionej”. Po pierwsze bowiem, działanie nią kierowane jest w pewien

SLH 6/2017 | str. 16 z 25 
sposób uporządkowane i możliwa jest jego „metodyczna” (Giddens, 2003, s. 60) kontynuacja, po drugie, jedną regułę można stosować w różnych okolicznościach. W tym miejscu widoczne jest podobieństwo między Giddensowską teorią strukturacji a teorią praktyki Bourdieu. Wszak jedność habitusu polega na tym, że podmiot działający w różnorodnych praktykach posługuje się tymi samymi schematami (działania, postrzegania, myślenia), wytworami jednorodnych (dla określonej klasy czy grupy) warunków. W Szkicu teorii praktyki Bourdieu określa nawet habitus jako „system trwałych, dających się przenosić dyspozycji, który integruje doświadczenia z przeszłości, w każdym momencie działa jako matryca percepcji, ocen oraz działań i umożliwia także wykonywanie nieskończenie zróżnicowanych zadań dzięki analogicznemu transferowi schematów umożliwiających rozwiązanie podobnie ukształtowanych problemów" (cyt. za: Sewell, 2006, s. 713$)^{19}$. Ale choć pojęcie schematu czy matrycy sugeruje możliwość ujęcia działania w zasady czy reguły (teoretyzując, często się to czyni), Bourdieu woli mówić o dyspozycjach powodujących podmiotem, a Giddens o regułach, z których podmiot może zdawać sobie sprawę. Stawką jest coś więcej niż hipotetyczna możliwość. Pojęcie reguły jest niezbędne brytyjskiemu socjologowi do teoretycznego sformułowania koncepcji refleksyjności. Twierdzi on, że „zdawanie sobie sprawy z reguł społecznych - znajdujące wyraz głównie w świadomości praktycznej - stanowi sedno owej «refleksyjności», która swoiście wyróżnia podmioty ludzkie" (Giddens, 2003, s. 71).

Giddens wskazuje różne własności regut, ujmowalne w opozycyjne pary. Reguły mogą być intensywne i płytkie, milczące i dyskursywne, niesformalizowane i sformalizowane, słabo i silnie usankcjonowane (Giddens, 2003, s. 71). By objaśnić swe stanowisko i ukazać, jak szeroko pojmuje „uogólnione procedury”, podaje on między innymi przykłady: reguł językowych, procedur stosowanych przy prezentowaniu się jednostek w interakcjach, reguł związanych z wyborami w krajach demokratycznych (w zbiorze tym znajdują się różnego typu reguły: jawne i niejawne, milczące i dyskursywne), zasad ubierania się (niekiedy są sformalizowane, np. w zawodach mundurowych, czasem niejasne i płynne). Większość reguł ma charakter niezwerbalizowany. Know-how aktorów pozwala im na odpowiednie zachowanie w danej sytuacji. Innymi słowy, większość reguł mających udział w odtwarzaniu społecznych praktyk trzeba ulokować nie w świadomości dyskursywnej, lecz w świadomości praktycznej podmiotu działającego.

Rozróżnienie to jest istotne i przywodzi na myśl rozważania Bourdieu o habitusie oraz logice praktyki i jego krytykę scholastycznych wypaczeń. Uwzględnienie świadomości praktycznej jest zdaniem Giddensa ważnym osiągnięciem, które odróżnia jego teorię od

19 Definicję tę przytacza też William H. Sewell Jr., który łączy Giddensa i Bourdieu w swoim rozumieniu schematów jako dających się przenosić i uogólnić procedur stosowanych w kształtowaniu życia społecznego. Pozostawiam tłumaczenie cytatu Bourdieu z artykułu Sewella (tłumaczenie z angielskiej wersji Le sens pratique), jako że jest trafniejsze. W polskiej wersji zamiast „dające się przenosić” mamy „przekazywalne”. Całe zdanie brzmi: „Praktyka jest konieczna, ale zachowuje też względna autonomię wobec sytuacji rozpatrywanej w jej punktowej bezpośredniości, bowiem jest produktem dialektycznej relacji między sytuacją a habitusem rozumianym jako system trwałych i przekazywalnych dyspozycji, który, obejmując wszystkie przeszłe doświadczenia, działa w każdej chwili jak matryca postrzeżeń, ocen i działań i umożliwia wypełnienie nieskończenie zróżnicowanych zadań dzięki analogicznym transferom schematów pozwalających rozwiązać podobne problemy i dzięki stałemu korygowaniu osiągniętych wyników, dialektycznie wytwarzanemu przez te rezultaty" (Bourdieu, 2007, s. 197). 
innych teorii socjologicznych zajmujących się problemem struktury, od teorii obiektywistycznych ${ }^{20}$ i psychoanalizy Freuda, do której się odwołuje. W polemice z wiedeńskim uczonym Giddens twierdzi, iż świadomość praktyczna, dotycząca tego, co się „po prostu czyni", bez konieczności ubierania tego w słowa, nie jest tożsama z nieświadomością: między świadomością dyskursywną a praktyczną nie ma przepaści poznawczej ${ }^{21}$. Według Giddensa nieświadomymi należy określić treści wyparte ze świadomości lub występujące w niej w postaci zniekształconej. Taka jest często motywacja działania, którą Giddens sytuuje u podstaw swego stratyfikacyjnego modelu podmiotu działającego (Giddens, 2003, s. 53). Być może zniuansowane podejście do pojęcia reguły stanowi alternatywę wobec (niekonsekwentnego) wykluczenia go z horyzontu opcji teoretycznych.

\section{Czy możliwe jest spojrzenie z zewnątrz?}

Jeszcze inaczej refleksje Wittgensteina na temat języka i działania interpretuje Michel de Certeau, autor pracy Wynaleźć codzienność. Sztuki działania (2008)²2, który biorąc je jako punkt wyjścia do własnych rozważań o specyfice praktyk, zawierających znane rozróżnienie strategii i taktyki ${ }^{23}$, dokonał także często powtarzanej krytyki teorii Bourdieu. Certeau odnosi się przede wszystkim do koncepcji habitusu (trzeba mieć na uwadze, że w momencie pisania swojej pracy opierał się przede wszystkim na Szkicu teorii praktyki i Dystynkcji, choć mógł znać również inne prace Bourdieu wydane do roku 1980) i zwraca uwagę na kołowy ruch teorii praktyki Bourdieu. Według autora Zmysłu praktycznego „Praktyki wytwarzane przez habitus jako generator strategii pozwalających stawić czoło nieprzewidzianym i wciąż nowym sytuacjom” są zdeterminowane przez „niegdysiejsze warunki wytworzenia ich zasady produkcji i dlatego zawsze dążą do odtworzenia obiektywnych struktur, których w ostatecznej analizie są wytworem" (Bourdieu, 2007, s. 193). Konsekwencją takiego ujęcia jest w ocenie Certeau odebranie praktykom impulsu twórczego, zdolności wynajdywania, i pozostawienie tej roli wyłącznie strukturom. Trafnie ujęła to współautorka drugiego tomu Wynaleźć codzienność. Luce Giard ocenia, że z perspektywy praktyk, tak jak przedstawia je Bourdieu, nie zdarza się nic nowego:

ani rozszerzenie gustu przez przypadkowe odkrycie (posłyszana melodia w radiu, która zwróci uwagę, afisz w nowym stylu graficznym, który przykuje spojrzenie), ani pozostawia-

20 Świadomość praktyczną wnikliwie, w ocenie Giddensa, opisały etnometodologia i fenomenologia.

21 W odróżnieniu od Bourdieu Giddens zwraca uwagę na społeczne zróżnicowanie zdolności do przekraczania tej granicy (zależy ona od doświadczenia, socjalizacji, także okoliczności) (Giddens, 2002, s. 51).

22 Autorem pierwszego tomu pracy (L'invention du quotidien. Vol. 1: Arts de faire, 1980) jest Certeau, drugi napisali przede wszystkim Luce Giard i Pierre Mayol (Giard dołączyła do pracy dwa artykuły Certeau). Angielska wersja książki nosi tytuł The Practice of Everyday Life. Pierwszy tom opublikowano w 1984 roku. Był to jedyny angielski przekład, jaki mógł nadzorować autor. To on zaproponował przekształcenie tytułu w angielskojęzycznym przekładzie tak, aby zawarło się w nim słowo „praktyka”. Zdaniem lana Buchanana doprowadziło to, wbrew intencjom de Certeau, do przekształcenia „praktyki” w quasi-obiekt (Buchanan, 2000, ss. 8-10). 0 wahaniu autora co do doboru pojęć świadczy opublikowany przed wydaniem książki artykuł Pratiques quotidiennes. Pour une semiotique de la culture ordinaire.

23 Spośród wszystkich pojęć Certeau te dwa są najczęściej przywoływane w literaturze nauk społecznych i humanistycznych, lecz źle rozumiane, komentuje Buchanan (Buchanan, 2000, s. 86). 
jące ślad spotkanie z nowym rozmówcą, który umożliwi poznanie nowych praktyk kulturowych, ani osobiste pragnienie samokształcenia się [...]. Teoria Bourdieu jest niezbita, ponieważ nie można jej „sfalsyfikować”: nie może się przydarzyć żaden „nieprzewidziany” fakt, który byłby niemożliwy do zinterpretowania w teorii i mógłby zachwiać jej podstawą (Certeau, Giard, \& Mayol, 2011, s. 168).

Praktyki są niemal całkowicie ograniczone, a nawet zdeterminowane przez obiektywne warunki i logikę pól. I w przypadku Bourdieu, uważa Certeau, logika myślenia ciąży ku miejscu: ujmowanemu jako dziedzictwo (habitus jest wszak „sposobem zamieszkiwania”, który polega na nieustannej akumulacji kapitału) i rozwój (a może należałoby powiedzieć - reprodukcja) ciała jednostkowego i zbiorowego. Habitus jest „miejscem dogmatycznym, jeśli przez dogmat rozumiemy potwierdzanie jakiejś rzeczywistości, potrzebnej dyskursowi do określenia jego totalnego charakteru" (Certeau, 2008, s. 60).

Certeau, jak wielu czytelników Bourdieu, zastanawia fakt, że francuski socjolog prawie tyle samo wysiłku poświęcał na skrupulatne opisanie swoistego sprytu praktyk, ich nieuchwytnej i niezapisywalnej „wirtuozerii”, co na zwieńczenie tych opisów teoretycznymi wywodami, których retoryka nie dopuszcza powątpiewania. Autor La Possession de Loudun widzi w tym gest wychodzenia - ku podstępnym taktykom - i powrotu - do racjonalności nauki. Stawia sprawę bardzo poważnie i przewrotnie zarazem: „Czyż jednak ów pośpieszny powrót nie świadczy o jego znajomości, śmiertelnego być może, niebezpieczeństwa, na jakie naukowa wiedza zostaje wystawiona przez owe nazbyt inteligentne praktyki?" (Certeau, 2008, s. 64). Aby uciec owemu niebezpieczeństwu i móc rościć sobie pretensje do naukowego, dyskursywnego uchwycenia prawdy praktyk, Bourdieu hipostazuje w postaci habitusu „rzeczywistość mistyczną” (Certeau, 2008, s. 60), „byt” niewidzialny i nieweryfikowalny.

Bourdieu uważał, że jego prace są wolne od niedogodności i trudności związanych z pojęciem reguły. Naraził się jednakże na liczne głosy sprzeciwu, gdy eksponował nieświadome czynniki sprawcze zachowań. Społeczeństwo może być systemem tylko za cenę nieświadomości - takie założenie zdaniem Certeau jest warunkiem totalizacji, której dokonuje Bourdieu w swych badaniach społeczeństwa francuskiego. Ten sposób myślenia prowadzi na powrót do tradycyjnej etnologii, która zawsze przypisywała jakiejś wyizolowanej grupie spójność i nieświadomość. Bourdieu wprowadza zatem do socjologii, zauważa autor Heterologii, element etnologiczny (Certeau, 2008, ss. 57-58). Być może jednak ten jakoby „etnologiczny” element jest zarazem „źródłowo” socjologiczny: znaleźć go można w pismach Durkheima. Koncepcja nieświadomego charakteru zjawisk społecznych jest integralnym elementem socjologii Durkheimowskiej, rozwiniętym następnie przez Maussa, a szczególnie eksponowanym przez Lévi-Straussa (Tarkowska, 1974, s. 150) (zatem etnologów czy antropologów) i, dodajmy, z pewnością podjętym przez Bourdieu. Certeau dochodzi do krytycznego i zaskakującego być może wniosku: dyskurs Bourdieu w nieświadomości praktykuje to, co wie, jest zatem w końcu samą „uczoną niewiedzą”, jaką według socjologa mają być nieświadomie inteligentne działania generowane przez habitus.

SLH 6/2017 | str. 19 z 25 
W pracy Wynaleźć codzienność Certeau powołuje się na Wittgensteina, który pokazał, że w próbie uchwycenia i opisu praktyk życia codziennego nie możemy wykroczyć poza język (potoczny, zwykły) ani naszą historyczność24 ${ }^{4}$. Zbliżone stanowisko co do możliwości reprezentowania praktyk i praktycznego rozumienia ich swoistości, zwłaszcza jeśli wychodzi się od Wittgensteina, prezentują Hubert Dreyfus i Paul Rabinow (1999) oraz Schatzki. Zgodnie z „wrażliwością Wittgensteinowską”, argumentuje ten ostatni, praktycznego rozumienia „nie można adekwatnie ująć w słowa” (Schatzki, 1996, s. 150). Schatzki przyznaje się do konfuzji wywołanej tym, że Bourdieu wydaje się zdawać sobie z tego sprawę, a jednocześnie konstruuje diagramy, modele i schematy logiki praktycznej właściwej praktykom rzeczywistym. Bourdieu utrzymuje, że modele praktyki i ujawniane przez nie „opozycje, równoważności i analogie mają wartość tylko dopóty, dopóki bierze się je za to, czym są, czyli za modele logiczne, które w sposób zarazem najbardziej spójny i ekonomiczny oddają jak największą liczbę zaobserwowanych faktów" (Bourdieu, 2008, s. 19), „naukowa konstrukcja potrafi uchwycić zasady logiki praktycznej tylko przez zmianę jej natury" (Bourdieu, 2008, s. 122), a przy tym charakteryzuje swoją metodę i cele jako bliskie metodzie i zamiarom Wittgensteina: „skonstruowałem dla rozmaitych dziedzin praktyki [...] diagramy, które wykorzystują szczególną właściwość schematu synoptycznego; mianowicie, jak pisze Wittgenstein, «pozwalają nam (one) zrozumieć, czyli dokładnie rzecz biorąc, zobaczyć korelacje»” (Bourdieu, 2008, s. 17).

Rozważania te prowadzą nieuchronnie do ogólniejszego, fundamentalnego wręcz problemu wspólnego wielu teoriom społecznym i humanistycznym: czy istnieje metoda konceptualizacji praktyki w sposób niewypaczony? Jedna z odpowiedzi na to pytanie brzmi: tylko za pomocą socjologicznej poetyki (przeciwstawionej teorii, co nie znaczy, jak sądzę, antyintelektualnej), poetyki wykraczającej „poza drogę teorii (beyond the way of the theory)”. John Shotter twierdzi, że uwagi Wittgensteina są właśnie poetyckie: „Dzięki troskliwemu doborowi ilustracji, porównań, analogii, metafor czy «obrazów» Wittgenstein wskazuje nowe sposoby mówienia, które nie tylko sprawiają, że wyczuwamy niezauważalne wcześniej rozróżnienia i relacje, ale także nowe powiązania i stosunki między owymi sposobami a resztą naszych poczynań" (Shotter, 1995) ${ }^{25}$. Shotter wierzy, iż poetykę zawierającą „rozumienie relacjonalne” można w sposób uzasadniony przeciwstawić „rozumieniu reprezentacjonistycznemu". Kontynuowanie dzieła Wittgensteina polegałoby na podjęciu się tworzenia takiej socjologicznej poetyki.

W pracach Bourdieu napotykamy zapadające w pamięć obrazy i sugestywne metafory, które mają odsłaniać to, co było dla nas niewidoczne, denaturalizować to, co pozornie naturalne (bo znaturalizowane). Sam socjolog dostrzega nawet pewne podobieństwa między własnym stylem a sposobem pisania Prousta (Bourdieu,1990, s. 51).Jednocześnie nie

24 „Rozprawianie o języku wewnątrz zwykłego języka, bez możliwości opanowania go wzrokiem, bez spojrzenia z perspektywy odmiennego miejsca, oznacza pojmowanie go jako ze społu p raktyk, w które jest się włączonym i w które jest zaangażowana proza świata” (Certeau, 2008, s. 14; wyróżnienie moje). Sformułowanie „proza świata" to oczywiste nawiązanie do tytułu pracy Merleau-Ponty’ego (Proza świata. Eseje o mowie).

25 Wittgenstein rzeczywiście stworzył specyficzny styl, może nawet poetykę pomagającą dostrzegać rzeczy, które „uchodziły naszej uwadze, ponieważ stale mamy je przed oczami” (Wittgenstein, 2008, s. 178). 
chce rezygnować z naukowych roszczeń swojej teorii, jej empirycznej i obiektywistycznej orientacji. Natomiast opis codzienności autorstwa Certeau przyjmuje formę eksperymentu językowego. Wynaleźć codzienność istotnie zdaje się dziełem na poły poetyckim² ${ }^{26}$, mimo że wierzyć można Giard, iż Certeau i jego współpracownicy w badaniach ściśle przestrzegali reguł naukowości nakazujących wyznaczyć obszar przedmiotowy, wybrać metodę, stawiać hipotezy, weryfikować je itd. (Certeau i in., 2011, s. XIV). W grę wchodzi tu raczej pewien styl mówienia o praktykach życia codziennego niż tradycyjnie pojęta teoria. „Nasze kategorie wiedzy są wciąż jeszcze zbyt proste, a nasze modele analizy niewystarczająco dopracowane, abyśmy mogli rozważać pomysłowość codziennych praktyk” (Certeau i in., 2011, s. 236) - oznajmia Certeau ze smutkiem, ale i z nadzieją, odsuwając możliwość ich zrozumienia w przyszłość.

\section{Wittgenstein i kwestia praktyki - podsumowanie}

Ujęcia praktyki Giddensa czy Certeau nie są oczywiście wolne od wad. Przywołałam je z intencją pokazania, iż kontynuacja Wittgensteinowskiego sposobu myślenia w obszarze samego tylko nurtu teorii praktyk obiera rozmaite kierunki i przyjmuje różne postacie, a droga Bourdieu nie jest bynajmniej niekontrowersyjna. Choć Wittgenstein miał istotny wpływ na Bourdieu (francuski socjolog stwierdza wprost, że „pole” jest odpowiednikiem - „empirycznym urzeczywistnieniem” - „formy życia”; Bourdieu, 2004b, s. 82), sądzę, że jego opracowana systematycznie teoria socjologiczna wybiega znacznie poza gramatyczne, fragmentaryczne, wieloznaczne i najeżone pytaniami dociekania Wittgensteina. Nie ma sensu rozważanie, czy wszystkie „tezy” późnego Wittgensteina można pogodzić na przykład z teorią habitusu i pola. Relację Bourdieu do autora Dociekań trudno jednoznacznie zinterpretować także ze względu na charakter Wittgensteinowskiego stylu i metody. W konsekwencji ujęcia tej relacji nierzadko zawierają - może nawet muszą zawierać - oceny tego, co jest typowe dla Wittgensteinowskiej „wrażliwości”, Wittgensteinowskiego „podejścia” czy „ducha”.

Sądzę, że kwestionowanie przydatności i adekwatności pojęcia reguły (ze względów filozoficznych, metodologicznych i empirycznych) do badania i opisywania ludzkich praktyk powiązane z krytyką intelektualizmu - według wielu antropologów i socjologów tak cenny element w pismach Bourdieu - nie musi pociągać za sobą ani dominacji perspektywy obiektywistycznej czy determinizmu, ani redukowania wielości celów ludzkich działań do nieświadomie interesownych. Jednakże przeplatanie się w argumentacji Bourdieu pojęć „interes” i illusio - które oznacza „stan pochłonięcia grą, stan, w którym uważa się, że gra jest warta świeczki” (Bourdieu, 2009, s. 114)27, pragnienie poddane sublimacji,

26 Rozdział cytowanej przeze mnie pracy poświęcony Certeau Highmore uznał za stosowne zatytułować „Michela de Certeau poetyka życia codziennego" (Michel de Certeau's Poetics of Everyday Life) (Highmore, 2002).

27 Co ciekawe, Bourdieu zauważa w Męskiej dominacji, że kobiety nie dają się wciągać w społeczne gry o władzę w tym samym stopniu co mężczyźni, a jeśli pochłonięte są grą (w której uczestniczy partner), „zdarza się”, że nie zdają sobie sprawy „z jej istoty i stawek” (Bourdieu, 2004a, s. 93). 
uzyskujące swą specyfikę w określonym środowisku społecznym czy polu - sprzyja zatarciu różnicy między zamieszkiwaniem zawsze już sensownego świata i zaangażowaniem w jego sprawy a nieustannym dążeniem do (symbolicznego lub materialnego) zysku.

Mimo iż za swoje osiągnięcie Bourdieu uważa sprzeciw wobec ekonomizmu, który interes rozumie ahistorycznie, to wprowadzając „materialistyczny sposób myślenia” (Bourdieu \& Wacquant, 2001, s. 101), zakłada, że każde działanie jest nakierowane (raczej nieświadomie) na maksymalizację kapitału czy - w społeczeństwach złożonych na interes wyznaczony przez dane pole (położenie podmiotu działającego w tym polu i jego trajektorię). Wydaje się zatem, iż jego naukowe, refleksyjne spojrzenie z zewnątrz jest perspektywą panekonomiczną. Sugeruje, że w każdej relacji i w każdej sytuacji między jednostkami rozgrywa się rywalizacja - w tle, jeśli nie na pierwszym planie. Nawet w bezinteresowną jakoby wymianę darów w rzeczywistości jest uwikłany interes, trudno dostrzegalny dzięki upływowi czasu między darem a odwzajemnieniem oraz umiejętnym zabiegom obytych z tradycją podmiotów działających ${ }^{28}$.

Dla wizji świata społecznego, którą odnajdujemy w pracach Bourdieu, podobnie jak w marksizmie kluczowy jest podział na dominujących i zdominowanych. I podobnie jak w tamtej tradycji pracy naukowej Bourdieu (a także jego zaangażowaniu politycznemu) przyświeca cel obnażania niesprawiedliwości. Skuteczność i przemożna siła dominacji opiera się według Bourdieu na tym,że dominacja pozostaje nierozpoznana. Wielu innych czynników kształtujących nasz los możemy nie być świadomi (co nie znaczy, że tkwią w nieświadomości), a zadaniem badacza jest te zjawiska i ich związki dostrzegać, opisywać i tłumaczyć, a także krytykować. Niemniej czym innym jest docierać, niczym Hipokrates, do tego, co niewidoczne, odkrywać obiektywne determinanty cierpienia (Bourdieu, 1999, ss. 628-629), a czym innym z góry znać prawdziwy sens, motywację i cel wszelkich ludzkich działań. Być może trajektorie naszych ścieżek układają się we wzór mniej czytelny, niż sądzi Bourdieu²9. Nieczytelność trudno jednak uczynić fundamentem krytyki.

\section{Bibliografia}

Berger, P., \& Luckmann, T. (1983). Społeczne tworzenie rzeczywistości (J. Niżnik, Tłum.). Warszawa: Wydawnictwo Naukowe PWN.

Bourdieu, P. (1990). In other words: Essays towards a reflexive sociology (M. Adamson, Tłum.). Stanford: Stanford University Press.

28 Zagadnienie wymiany darów zajmuje $\mathrm{w}$ teorii Bourdieu miejsce szczególne. Według niego wymiana ta stanowi „paradygmat wszelkich operacji, dzięki którym symboliczna alchemia wytwarza tę rzeczywistość negującą rze"czywistość”, czyli rzeczywistość wyobrażeń grupy zakrywającą „obiektywną” rzeczywistość społeczną (Bourdieu, 2008, s. 149). Problem ten podjęłam w tekście Przemoc daru. Pierre Bourdieu o podwójnej prawdzie gier społecznych (Pancewicz-Puchalska, 2008).

29 Metafora ta jest nawiązaniem do Certeau i jego próby uchwycenia specyfiki taktyk: „W technokratycznie skonstruowanej, zapisanej i funkcjonalnej przestrzeni trajektorie, po których poruszają się konsumenci, tworzą nieprzewidywalne zdania, częściowo nieczytelne «drogi w poprzek». Mimo że zbudowane ze słów w istniejących językach i zgodnie z zasadami składni, kreślą one podstępy odnoszące się do innych celów i pragnień nieokreślonych ani nieuchwyconych przez systemy, w obrębie których powstają" (Certeau, 2008, s. XLI). 
Bourdieu, P. (1999). Postscript. W P. Bourdieu, A. Accardo, G. Balazs i in., The weight of the world: Social suffering in contemporary society (P. Parkhurs Ferguson i in., Tłum.). Stanford: Stanford University Press.

Bourdieu, P. (2002). Bachelors' ball (R. Nice, Ttum.). Chicago: University of Chicago Press.

Bourdieu, P. (2004a). Męska dominacja (L. Kopciewicz, Tłum.). Warszawa: Oficyna Naukowa.

Bourdieu, P. (2004b). Science of science and reflexivity (R. Nice, Tłum.). Chicago: University of Chicago Press.

Bourdieu, P. (2007). Szkic teorii praktyki poprzedzony trzema studiami na temat etnologii Kabylów (W. Kroker, Tłum.). Kęty: Wydawnictwo Marek Derewiecki.

Bourdieu, P. (2008). Zmyst praktyczny (M. Falski, Tłum.). Kraków: Wydawnictwo Uniwersytetu Jagiellońskiego.

Bourdieu, P. (2009). Rozum praktyczny: O teorii działania (J. Stryjczyk, Tłum.). Kraków: Wydawnictwo Uniwersytetu Jagiellońskiego.

Bourdieu, P., \& Wacquant, L. (1992). An invitation to reflexive sociology. Chicago: The University of Chicago Press.

Bourdieu, P., \& Wacquant, L. (2001). Zaproszenie do socjologii refleksyjnej (A. Sawisz, Tłum.). Warszawa: Oficyna Naukowa.

Bouvresse, J. (1999). Rules, dispositions, and the habitus. W R. Shusterman (Red.), Bourdieu: A critical reader (ss. 45-63). Oxford: Blackwell Publishers.

Buchanan, I. (2000). Michel de Certeau: Cultural theorist. London: Sage Publications.

Certeau, M. de. (2008). Wynaleźć codzienność: Sztuki działania (K. Thiel-Jańczuk, Tłum.). Kraków: Wydawnictwo Uniwersytetu Jagiellońskiego

Certeau, M. de, Giard, L., \& Mayol, P. (2011). Wynaleźć codzienność: T. 2. Mieszkać, gotować (K. Thiel-Jańczuk, Tłum.). Kraków: Wydawnictwo Uniwersytetu Jagiellońskiego.

Crary, A. (2009). O stosunku filozofii Wittgensteina do myśli politycznej (L. Rasiński, Tłum.). W A. Crary \& R. Read (Red.), Wittgenstein - nowe spojrzenie (ss. 147-178). Wrocław: Wydawnictwo Naukowe Dolnośląskiej Szkoły Wyższej.

Dreyfus, H., \& Rabinow, P. (1999). Can there be a science of existential structure and social meaning. W R. Shusterman (Red.), Bourdieu: A critical reader (ss. 84-93). Oxford: Blackwell Publishers.

Finkelstein, D. H. (2009). Wittgenstein o regułach i platonizmie (T. Zarębski, Tłum.). W A. Crary \& R. Read (Red.), Wittgenstein - nowe spojrzenie (ss. 73-96). Wrocław: Wydawnictwo Naukowe Dolnośląskiej Szkoły Wyższej.

Gerrans, P. (2005). Tacit knowledge, rule following and Pierre Bourdieu's philosophy of social science. Anthropological Theory, 5(1), 53-74. https://doi.org/10.1177/1463499605050869

Giddens, A. (2002). Nowoczesność i tożsamość: „Ja” i społeczeństwo w epoce późnej nowoczesności (A. Szulżycka, Tłum.). Warszawa: Wydawnictwo Naukowe PWN.

Giddens, A. (2003). Stanowienie społeczeństwa: Zarys teorii strukturacji (S. Amsterdamski, Tłum.). Poznań: Wydawnictwo Zysk i Spółka.

Giddens, A. (2009). Nowe zasady metody socjologicznej: Pozytywna krytyka socjologii interptretatywnych (G. Woroniecka, Tłum.). Kraków: Zakład Wydawniczy „Nomos”.

Highmore, B. (2002). Everyday life and cultural theory: An introduction. London: Routledge. https://doi. org/10.4324/9780203464229

Kripke, S. (2007). Wittgenstein o regułach i języku prywatnym (K. Posłajko \& L. Wroński, Tłum.). Warszawa: Fundacja Aletheia.

McGinn, M. (1997). Wittgenstein and the „philosophical investigations”. London: Routledge.

Pancewicz-Puchalska, M. (2008). Przemoc daru: Pierre Bourdieu o podwójnej prawdzie gier społecznych. W M. Baczewska (Red.), Portrety przemocy: Filozofia - spoteczeństwo - kultura (ss. 50-61). Lublin: Wydawnictwo Akapit. 
Pancewicz-Puchalska, M. (2011). Praktykowanie kultury poprzez ciało - o pewnych wątkach fenomenologicznych w socjologii Pierre’a Bourdieu. W K. Łukasiewicz \& I. Topp (Red.), Kultura jako cultura (ss. 127-145). Wrocław: Wydawnictwo Uniwersytetu Wrocławskiego.

Schatzki, T. R. (1996). Social practices: A Wittgensteinian approach to human activity and the social. Cambridge: Cambridge University Press. https://doi.org/10.1017/CB09780511527470

Schatzki, T. R. (1997). Practices and actions: A Wittgensteinian critique of Bourdieu and Giddens. Philosophy of the Social Sciences, 3(27), 283-308. https://doi.org/10.1177/004839319702700301

Schatzki, T. R. (2000). Wittgenstein and the social context of an individual life. History of the Human Sciences, 13(1), 93-107. https://doi.org/10.1177/09526950022120629

Schatzki, T. R., Knorr-Cetina, K., \& Savigny, E. von (2001). Practice turn in contemporary theory. London: Routledge.

Sewell, W. H. Jr. (2006). Teoria struktury: Dwoistość, podmiotowość sprawcza a transformacja (A. Zawadzka \& W. Derczyński, Tłum.). W A. Jasińska-Kania, L. M. Nijakowski, J. Szacki, \& M. Ziółkowski (Wyb.), Współczesne teorie socjologiczne (T. 2, ss. 700-722). Warszawa: Wydawnictwo Naukowe Scholar.

Shotter, J. (1995). Wittgenstein's world: Beyond the way of theory toward a social poetics. Pobrano 3 października 2013, z http://www.massey.ac.nz/ alock/virtual/poetics.htm

Stone, M. (2009). Wittgenstein o dekonstrukcji (K. Liszka, Tłum.). W A. Crary \& R. Read (Red.), Wittgenstein nowe spojrzenie (ss. 107-145). Wrocław: Wydawnictwo Naukowe Dolnośląskiej Szkoły Wyższej.

Swartz, D. (1997). Culture and power: The sociology of Pierre Bourdieu. Chicago: The University of Chicago Press.

Szacki, J. (1991). Obiektywizm i subiektywizm w socjologii. W J. Szacki, Dylematy historiozofii idei oraz inne szkice i studia (ss. 167-217). Warszawa: PWN.

Szacki, J. (2002). Historia myśli socjologicznej. Warszawa: Wydawnictwo Naukowe PWN.

Tarkowska, E. (1974). Ciaggłość i zmiana socjologii francuskiej: Durkheim, Mauss, Lévi-Strauss. Warszawa: Państwowe Wydawnictwo Naukowe.

Taylor, C. (1993). To follow a rule... W C. Calhoun, E. LiPuma, \& M. Postone (Red.), Pierre Bourdieu: Critical perspectives (ss. 45-60). Cambridge: Polity Press.

Wacquant, L. (1992). Toward a social praxeology: The structure and logic of Bourdieu's sociology. W P. Bourdieu \& L. Wacquant, An invitation to reflexive sociology (ss. 1-59). Chicago: The University of Chicago Press.

Wacquant, L. (1998). Pierre Bourdieu. W M. Stones (Red.), Key sociological thinkers (ss. 215-230). London: Macmillan Press. https://doi.org/10.1007/978-1-349-26616-6_17

Wacquant, L. (2001). Wprowadzenie. W P. Bourdieu \& L. Wacquant, Zaproszenie do socjologii refleksyjnej (A. Sawisz, Tłum.) (ss. 8-41). Warszawa: Oficyna Naukowa.

Winch, P. (1995). Idea nauki o społeczeństwie i jej związki z filozofią (B. Chwedeńczuk, Tłum.). Warszawa: Oficyna Naukowa.

Wittgenstein, L. (1980a). Culture and value (G. H. von Wright, Red., P. Winch, Tłum.). Chicago: University of Chicago Press.

Wittgenstein, L. (1980b). Remarks on philosophy of psychology (G. E. M. Anscombe, Tłum.). Oxford: Basil Blackwell.

Wittgenstein, L. (1993). Big typescript sections 86-93. W J. Klagge \& A. Nordmann (Red.), Philosophical occasions 1912-1951. Indianapolis, IN: Hackett.

Wittgenstein, L. (2000). Uwagi różne (M. Kowalewska, Tłum.). Warszawa: Wydawnictwo KR.

Wittgenstein, L. (2008). Dociekania filozoficzne (B. Wolniewicz, Tłum.). Warszawa: Wydawnictwo Naukowe PWN.

SLH 6/2017 | str. 24 z 25 
Wittgenstein the saviour? The problem of rules in Pierre Bourdieu's theory of practice

Abstract: The text constitutes a thorough and exhaustive analysis of the impact of Ludwig Wittgenstein's philosophy on Pierre Bourdieu's theory of practice and especially on his notions of practical sense and logic of practice. The author first considers both philosophers' attitude to objectivism. Then she proposes a reading of Wittgenstein's theory that might prove useful and inspiring in the sociological field. In the final section, the author analyses the other, partly oppositional in relation to Bourdieu's, theories of practice, proposed by Anthony Giddens and Michel de Certeau, putting them in the light of Wittgenstein's analyses.

Keywords: Pierre Bourdieu; Ludwig Wittgenstein; habitus.

Article No. 1555

DOI: $10.11649 /$ slh.1555

Citation: Pancewicz-Puchalska, M. (2017). Wybawca Wittgenstein? Problem reguł w teorii praktyki Pierre’a Bourdieu. Studia Litteraria et Historica, 2017(6). https://doi.org/10.11649/slh.1555.

This is an Open Access article distributed under the terms of the Creative Commons Attribution 3.0 PL License, which permits redistribution, commercial and non-commercial, provided that the article is properly cited. www.creativecommons.org/licenses/by/3.0/pl

(c) The Author(s) 2017

Publisher: Institute of Slavic Studies, Polish Academy of Sciences, Warsaw.

Author: Magdalena Pancewicz-Puchalska, Wrocław.

Correspondence: magdap-p@o2.pl

The preparation of this article was financed within the statutory activities of the Institute of Cultural Studies, University of Wrocław.

Competing interest: The author has declared she has no competing interest. 